\title{
The Disruption of \\ Lysosome-like Particles of Solanum tuberosum Cells during Infection by Phytophthora erythroseptica Pethybr.
}

\author{
By D. PITT AND CLARE COOMBES \\ Department of Botany, University of Exeter
}

(Accepted for publication 2 April 1968)

\begin{abstract}
SUMMARY
Histochemical methods showed that tuber tissue and tissue culture cells of Solanum tuberosum contained phase-dense particles which absorbed neutral red and fluorescent dye, and particles which contained acid phosphatase and a non-specific esterase. It is suggested that these structures may be comparable to the lysosomes of animal tissues and the lysosome-like structures of plant cells which possess similar and additional properties. During infection of Solanum tissues by Phytophthora erythroseptica there was swelling and disruption of these host cell particles, accompanied by the release of acid phosphatase and esterase. Biochemical assay for acid phosphatase confirmed that infection of host cells resulted in the liberation of acid phosphatase from a particulate to the supernatant fiuid fraction of cell homogenates.
\end{abstract}

\section{INTRODUCTION}

Evidence from work on animal tissues indicates that lysosomes are involved in a variety of ways in cellular injury and in tissue regression (de Duve, 1963). It is now apparent that virus infection of cells (Allison \& Mallucci, 1965; Mallucci \& Allison, 1965) and actions of bacterial toxins (Bernheimer \& Schwartz, 1964) may result in permeability changes in lysosomal membranes, causing the release into the cytoplasm of enzymes which initiate cytopathic effects that may lead ultimately to the death of the host cells. However, it is not certain whether the activities of these released lysosomal enzymes are a cause or a consequence of cell death. It has been shown (Gahan, 1965, 1967; Pitt \& Walker, 1967; Pitt, 1968) that plant cells contain particles having affinities with the lysosomes of animal cells, but at present there is no information about the role of these structures in plant tissue pathology. The present work was designed to investigate the presence of such structures in tuber tissues of Solanum tuberosum and to examine their fate during infection with Phytophthora erythroseptica, the fungus responsible for pink rot disease of potatoes.

\section{METHODS}

Organisms. Phytophthora erythroseptica Pethybr. was isolated from a tuber of Solanum tuberosum cv. Majestic showing symptoms of pink rot disease. When reinoculated into healthy tubers disease development was rapid.

Potato tubers cv. Majestic were grown in the Botanical Gardens of the University of Exeter and used throughout this investigation. Tubers were washed and surface sterilized in $70 \%(\mathrm{v} / \mathrm{v})$ ethanol in water, wound-inoculated with discs of a malt- 
extract agar culture of Phytophthora erythroseptica, and incubated for 4 to 7 days at $22^{\circ}$. Appropriate controls were inoculated with discs of sterile malt extract agar.

Callus cultures of tubers of Solanum tuberosum were obtained and grown by the method of Ingram \& Robertson (1965) on media solidified with $0.5 \%$ (w/v) Oxoid agar or as suspension cultures on liquid medium agitated at $150 \mathrm{rev} . / \mathrm{min}$. on a rotary mechanical shaker at $25^{\circ}$.

Inoculation of tissue cultures. Callus tissues grown for 4 to 6 weeks to a diameter of 3 to $4 \mathrm{~cm}$. were divided into two portions and separated spatially on the medium. One portion was inoculated with a disc of the fungus culture and the other, serving as a control, was inoculated with a disc of sterile malt-extract agar. The tissues were then incubated for a further I to 4 days with intermittent examination. Suspension cultures were inoculated with discs of an agar culture of the fungus and shaken for a further period before use.

Microscopy. All observations were made with a Leitz 'Ortholux' microscope equipped with a transmitted light condenser, a Heine phase condenser and an incident light attachment permitting the use of a $250 \mathrm{~W}$ high-pressure mercury vapour lamp for fluorescence microscopy.

Histochemical methods. These were all established methods and were made on fresh hand-cut sections of infected and uninfected tuber tissues and on fresh callus tissue or free cells from suspension cultures. Tissue-culture material was fixed where necessary for $16 \mathrm{hr}$ in cold Baker's formol-calcium or neutral formalin at o to $4^{\circ}$. Small blocks of tuber tissue were similarly fixed and sectioned on a freezing microtome at 25 to $50 \mu$.

Acid phosphatase. (a) The standard coupling azo dye method (Grogg \& Pearse, 1952) was done on fresh and fixed sections and tissue culture material with sodium $\alpha$-naphthyl phosphate as substrate (Koch-Light Laboratories Ltd.) and Fast garnet GBC salt (G. T. Gurr, Ltd.) with incubation for 15 to $60 \mathrm{~min}$. (b) The post-coupling azo dye method (Rutenberg \& Seligman, 1955) was used on similar tissues with sodium 6-benzoyl-2-naphthyl phosphate (Koch-Light, Ltd.) and incubation for I hr at $37^{\circ}$ followed by coupling with Fast blue B salt (G. T. Gurr, Ltd.) at $0^{\circ}$. (c) The Gomori (1952) lead nitrate method was also used, but was found unsuitable for potato tuber tissue because of heavy non-specific lead deposits produced over a wide range of experimental conditions.

The specificity of these methods was checked by the use of $10^{-2} \mathrm{M}$-sodium fluoride in the incubation medium, by use of heated tissues and by omission of the substrates and the coupling dyes. In addition, tissues were pre-incubated in $0.25 \%(\mathrm{w} / \mathrm{v})$ Triton $\mathrm{X}$-I00 in $0.05 \mathrm{M}$-acetate buffer $(\mathrm{pH} 5.0)$ and frozen and thawed several times before staining for acid phosphatase in order to satisfy certain of the criteria proposed by Gahan (1967) for the identification of lysosome-like particles.

Esterases. The methods used included: the indoxyl procedure of Holt (1958) with $O$-acetyl-5-bromoindoxyl (K and K Laboratories Inc., New York) as substrate; the $\alpha$-naphthyl acetate coupled with Fast blue B salt (G. T. Gurr, Ltd.) or hexazotised $p$-rosaniline method of Davis \& Ornstein (1959); the Gomori (1952) procedure with Naphthol-AS acetate (G. T. Gurr, Ltd.) coupled with Fast red TR salt (G. T. Gurr, Ltd.); the thioacetic acid method (Wachstein, Meisel \& Falcon, I96I) on fresh and fixed tissues.

Other hydrolases. Attempts to show activities of several other hydrolases included the use of the following methods: of Rutenberg et al. (1952) for arylsulphatase; of 
Seligman et al. (1954) for $\beta$-D-glucuronidase; of Rutenberg et al. (1958) for $\beta$-Dgalactosidase; of Vorbrodt (196I) for acid deoxyribonuclease II (DN-ase II).

Uptake of vital dyes and fluorochromes. Considerable evidence is now available that neutral red is taken up in non-toxic quantities and concentrated within the lysosomes of animal cells (Ogawa, Mizunu \& Okamoto, 196I; Cohn \& Wiener, 1963). The potato tuber tissue culture cells used in the present work accumulated this dye when incubated in culture media containing neutral red (G. T. Gurr, vital and fluorochrome) at $\mathrm{I} / 20,000$ concentration for $2 \mathrm{hr}$ in darkness. It was also found that cells stained for neutral red granules and fixed in $6 \%(\mathrm{w} / \mathrm{v})$ glutaraldehyde in $0 . \mathrm{I} \mathrm{M}$-cacodylate buffer $(\mathrm{pH} 7 \cdot 4$ ) and then stained for acid phosphatase by the standard coupling azo dye method contained a proportion of neutral red granules which also contained acid phosphatase.

Sections of healthy and uninfected potato tuber tissues were stained in neutral red and then fixed and stained for acid phosphatase by the above procedure.

Animal cell lysosomes accumulate acridine orange and other aminoacridines (Koenig, 1963; Robbins, Marcus \& Gonatus, 1964) and fluoresce under appropriate conditions. In the present work euchrysin $3 \mathrm{R}$ (E. Gurr, Ltd.) was added to free cell suspensions at a final concentration of $\mathrm{I}$ in $5 \times 10^{4}$; the cells were incubated for $\mathrm{I} \mathrm{hr}$ at $25^{\circ}$ in darkness, washed, mounted in fresh medium containing fluorochrome. The preparations were examined by fluorescence microscopy with light of wavelength 400 to $500 \mathrm{~m} \mu$ obtained by use of a BG I2 exciter filter and an appropriate suppressor filter. The cytoplasm fluoresced pale green with brighter green fluorescence in the nucleus and nucleolus. The cytoplasm contained numerous bright green or orange fluorescent particles, the colour apparently depending upon the amount of dye absorbed (Allison \& Mallucci, 1965). Infected tuber tissue culture cells were examined in a similar manner, dye being added $\mathrm{I} \mathrm{hr}$ before examination of samples. For comparison a sample of infected cells was mounted and incubated in a damp chamber and intermittent observations made on a single cell over $24 \mathrm{hr}$ (Pl. 4, fig. 7, 8). Hand-cut sections of infected and uninfected tuber tissues of Solanum tuberosum were stained with similar dye concentrations and observed by similar methods.

Biochemical methods. Homogenization of infected callus tissue was done in such a way as to minimize disruption of the fungal component. Experiments showed that the addition of fungal samples to infected and uninfected callus cells followed by homogenization and centrifugation resulted in accumulation of the fungal component within the cell debris deposit; only a negligible amount was found in the supernatant fluid and particulate fractions used in subsequent work.

Infected and uninfected callus tissues were harvested and homogenized separately for $4 \mathrm{~min}$. in $0.25 \mathrm{M}$-sucrose by using a Pyrex glass homogenizer rotating at about $200 \mathrm{rev}$. $/ \mathrm{min}$. at 0 to $4^{\circ}$. The homogenate was then centrifuged for Io min. at $2000 \mathrm{~g}$ at $0^{\circ}$, the deposit discarded, and the supernatant fluid further centrifuged for $20 \mathrm{~min}$. at $35,000 \mathrm{~g}$ at $0^{\circ}$. The acid phosphatase within the supernatant fluid and particulate fractions was then determined by the method of Berthet \& de Duve (I95I) with $\beta$-glycerophosphate (British Drug Houses) as a substrate and a reaction time of $20 \mathrm{~min}$. at $37^{\circ}$. Liberated phosphate was then determined by the method of Fiske \& SubbaRow (1925) with spectrophotometric readings at $660 \mathrm{~m} \mu$ taken $10 \mathrm{~min}$. after addition of the molybdate. Appropriate blanks were determined along with readings made on reaction mixtures containing $\mathrm{O} \cdot \mathrm{O} \mathrm{I} \mathrm{M}-\mathrm{NaF}$. 


\section{RESULTS}

\section{Staining reactions of uninfected tissues of Solanum}

Living callus culture cells and suspensions of cells of tuber tissues of Solanum tuberosum contained phase-dense particles and structures which absorbed neutral red and euchrysin $3 \mathrm{R}$ (Pl. 4, fig. 9) in large quantities. Appropriate microscopy showed that the phase-dense particles were identical with those absorbing vital dyes and that these structures appeared as bright bodies when examined by dark-ground transmitted light microscopy. The particles observed by these methods were 0.2 to $2.0 \mu$ in diameter. Similar observations were made by using fresh hand-cut sections of potato tuber tissue. However, in this tissue only a proportion of the cells contained particles which absorbed neutral red and euchrysin.

Tuber tissue sections and tissue culture cells, either fixed or unfixed, contained numerous particles which stained brown by the standard coupling azo dye method with incubation for 15 to $30 \mathrm{~min}$. at $37^{\circ}$ (Pl. I, fig. I; Pl. 3, fig. 5). Similar particles were shown by the post-coupling azo dye method, but localization was less well defined. These methods showed an even distribution of particulate staining throughout the tissues, with higher local concentrations in the xylem parenchyma and phloem parenchyma of the vascular elements of sections (Pl. 2, fig. 3). With incubation for less than $30 \mathrm{~min}$. only slight diffuse staining of tissues was observed; longer periods of incubation resulted in a progressive increase in diffuse staining in all tissues, particularly in the vascular tissues.

Tissues subjected to freezing and thawing or incubation in Triton X-10o before incubation in the acid phosphatase test media showed slight diffuse staining and no particulate staining. Incubation of tissues in the presence of $\mathrm{NaF}$ or previous heating at $100^{\circ}$ resulted in the absence of staining.

The particles revealed by the acid phosphatase methods appeared spherical and were 0.2 to $2 \cdot 0 \mu$ in diameter.

Histochemical methods for esterase including the indoxyl, $\alpha$-naphthyl acetate coupled with hexazotized $p$-rosaniline and the thioacetic acid procedures showed particulate distribution of enzyme activities in the vascular tissues with some diffuse staining, but only slight particulate staining elsewhere in tuber sections. By using these methods with callus cells only slight diffuse staining was seen. However, fresh and fixed tuber sections and callus cells showed excellent particulate localization of esterase activity by using $\alpha$-naphthyl acetate as substrate coupled with Fast blue B at $0^{\circ}$, and with the Gomori (1952) procedure with Naphthol-AS acetate as the substrate coupled with Fast red TR salt with 30 to 60 min. incubation at $22^{\circ}$. Both particulate and diffuse staining were resistant to the effects of the esterase inhibitor diethyl- $p$-nitrophenyl phosphate at $\mathrm{IO}^{-3}$ and $\mathrm{IO}^{-5} \mathrm{M}$. Particles stained by these methods had a similar size and distribution to those demonstrated by the standard coupling azo dye method for acid phosphatase.

Slight diffuse and particulate staining was shown in fresh and fixed tuber sections by using the method for $\beta$-D-galactosidase, but attempts to demonstrate activities of arylsulphatase, $\beta$-D-glucuronidase and DN-ase II were unsuccessful. 


\section{Staining reactions of tissues of Solanum infected by Phytophthora erythroseptica}

Potato tubers that had been infected and incubated for 4 days at $22^{\circ}$ and then examined for acid phosphatase activity by the coupling azo dye method, using fresh hand-cut sections and microtome sections of formalin-fixed material, showed fewer particles (Pl. I, fig. 2) than uninfected tissues. Such particles as were visible were greatly enlarged and surrounded by areas of intense diffuse staining. Vital staining of these tissues with neutral red showed increased uptake of dye into swollen structures. By using the coupling azo dye method acid phosphatase activity was shown in these neutral-red granules after fixation in buffered glutaraldehyde. Tissues infected for a longer period, e.g. 7 days, still showed some enlarged particles containing acid phosphatase, but the staining was then generally diffuse (Pl. 2, fig. 4). At this stage of tissue infection neutral-red uptake was decreased and confined to a few swollen granules. The orange-fluorescing particles seen in healthy tissues were not observed in the infected tissues except in an occasional cell at the advancing edge of a disease lesion.

\section{Table I. Potato callus tissue infected with Phytophthora erythroseptica}

Acid phosphatase activity in particulate (P) and supernatant fluid (S) fractions of potato callus tissue.

\begin{tabular}{|c|c|c|c|c|}
\hline \multirow{3}{*}{ Tissue } & \multirow{2}{*}{\multicolumn{2}{|c|}{$\begin{array}{l}\begin{array}{c}\text { Activity of fractions. Inorganic } \\
\text { phosphate released }\left(\mu \mathrm{g} . \mathbf{P}_{\mathbf{i}} / 20 \mathrm{~min} . /\right. \\
\text { g. tissue })\end{array}\end{array}$}} & \multicolumn{2}{|c|}{$\begin{array}{l}\% \text { total activity }(\mathrm{P}+\mathrm{S} \\
\text { fractions }) \text { in fractions }\end{array}$} \\
\hline & & & $\mathbf{p}$ & $\mathbf{S}$ \\
\hline & $\mathbf{P}$ & $\mathbf{S}$ & & \\
\hline $\begin{array}{l}\text { Uninfected } \\
4 \text { days after } \\
\text { infection }\end{array}$ & $\begin{array}{r}142.5 \\
40.8\end{array}$ & $\begin{array}{r}79 \cdot 1 \\
123.6\end{array}$ & $\begin{array}{l}64 \cdot 3 \\
24 \cdot 8\end{array}$ & $\begin{array}{l}35 \cdot 7 \\
75 \cdot 2\end{array}$ \\
\hline
\end{tabular}

Tissue culture cells from infected callus cultures and from infected suspension cultures contained enlarged particles when stained by the coupling azo dye method for acid phosphatase (P1. 3, fig. 6). Samples of cells taken from suspension cultures to which neutral red and euchrysin $3 \mathrm{R}$ had been added showed slight enlargement, culminating in abrupt disruption of these particles over a period of $\mathrm{I}$ to 4 days (Pl. 4 , fig. 7,8 ). However, enlarged particles observed by vital staining never attained the size of those shown by the azo dye methods before disruption and liberation of their dye content into the cytoplasm. The appearance of infected tissues stained for nonspecific esterase was basically similar to that shown by using acid phosphatase staining methods, but diffuse staining was much less intense and swollen structures were fewer.

\section{Acid phosphatase assay of infected and uninfected cells of Solanum tuberosum}

To test the possibility indicated by histochemical methods that acid phosphatase is liberated from cell particles of Solanum during infection by Phytophthora erythroseptica, the activities of this enzyme in the particulate and supernatant fluid fractions of appropriate cell homogenates were examined. Results of a typical experiment are given in Table $\mathrm{I}$. 


\section{DISCUSSION}

There is convincing evidence for the existence in plant cells of structures which have attributes in common with the lysosomes of animal cells (Gahan, 1965, 1967; Pitt \& Walker, 1967; Pitt, 1968). Although there are marked similarities between these structures there are also differences. In many cases only acid phosphatase or a limited number of other lysosomal hydrolases have been shown in these plant cell particles and this has often been taken as sufficient proof of their lysosomal nature. Furthermore, structures absorbing fluorochromes in plant cells have not yet been identified with certainty as those containing acid hydrolases. Although structure-linked latency of enzyme activity has not been shown here in the lysosome-like particles of tuber tissue of Solanum tuberosum several of the criteria for lysosomes listed by Gahan (1967) have been fulfilled: possession of acid phosphatase and esterase activity, uptake of vital dyes and fluorochromes and the Triton X-100 and freezing and thawing effects on membrane permeability. The biochemical evidence is also convincing; but since other hydrolases have not yet been found in some of the particles containing acid phosphatase it cannot be said with certainty that such structures are lysosomes or spherosomes. However, it was suggested by Frey-Wyssling \& Mühlethaler (1965) that these two types of particle may be closely related, and Semadeni (1967) considers that the spherosomes may represent organelles equivalent to animal lysosomes.

During infection of tuber tissue of Solanum tuberosum by Phytophthora erythroseptica there is swelling and disruption of host cytoplasmic particles which have properties in common with lysosomes. This results in liberation of particulate acid phosphatase and esterase accompanied by rapid death of the host cells. It is possible that under appropriate conditions the activity of released acid phosphatase could account for some of the phosphate frequently reported to accumulate at sites of fungal infection. The precise factors involved in swelling and permeability changes of lysosomal membranes are not known, but the events observed in the present work bear a striking resemblance to those which follow virus infection of animal cells (Allison \& Mallucci, I965; Mallucci \& Allison, 1965) and the effects produced by bacterial toxins on lysosomes of rabbit leucocytes (Bernheimer \& Schwartz, I964). The present studies, like those with animal tissues, do not establish whether disruption of such particles is a cause or a consequence of cell death. However, changes in lysosomes and in the structures examined in the present work precede any other histological or histochemical changes so far detected in the infected cells.

\section{REFERENCES}

Allison, A. C. \& Mallucci, L. (1965). Histochemical studies of lysosomes and lysosomal enzymes in virus-infected cell cultures. J. exp. Med. I21, 463.

Bernheimer, A. W. \& Schwartz, L. L. (1964). Lysosomal disruption by bacterial toxins. J. Bact. 87, I 100.

BertheT, J. \& DE Duve, C. (195I). Tissue fractionation studies. I. The existence of a mitochondriallinked enzymically inactive form of acid phosphatase in rat-liver tissue. Biochem. J. 5o, I74.

COHN, Z. A. \& WIENER, E. (I963). The particulate hydrolases of macrophages. II. Biochemical and morphological response to particle ingestion. J. exp. Med. rr8, I009.

Davis, B. J. \& Ornstein, L. (I959). High resolution enzyme localization with a new diazo reagent, 'hexazonium pararosaniline'. J. Histochem. Cytochem. 7, 297. 
DE Duve, C. (1963). Lysosomes and cell injury. In Injury, Inflammation and Immunity. Ed. by L. Thomas, J. L. Urh and L. Grant. Baltimore: Williams and Wilkins Co.

Fiske, C. H. \& SubBaRow, Y. (1925). The colorimetric determination of phosphorus. J. biol. Chem. 66,375 .

Frey-Wyssling, A. \& MüHLEThaleR, K. (1965). In Ultrastructural Plant Cytology, p. 173. Amsterdam: Elsevier Publishing Co.

GaHAN, P. B. (1965). Histochemical evidence for the presence of lysosome-like particles in root meristem cells of Vicia faba. J. exp. Bot. 16, 350.

GaHAN, P. B. (1967). Histochemistry of lysosomes. Int. Rev. Cytol. 2r, I.

GOMORI, G. (1952). In Microscopic Histochemistry. Chicago: University Press.

Grogg, E. \& Pearse, A. G. E. (1952). A critical study of the techniques for acid phosphatase with a description of an azo dye method. J. Path. Bact. 64, 627.

Holt, S. J. (1958). Indigogenic staining methods for esterases. In General Cytochemical Methods. Ed. by J. F. Danielli, r, 375. New York: Academic Press.

Ingram, D. S. \& RoberTson, N. F. (1965). Interaction between Phytophthora infestans and tissue cultures of Solanum tuberosum. J. gen. Microbiol. 40, $43 \mathrm{I}$.

KoENIG, H. (1963). Intravital staining of lysosomes by basic dyes and metallic ions. J. Cell Biol. r9, $87 \mathrm{~A}$.

Mallucci, L. \& Allison, A. C. (I965). Lysosomal enzymes in cells infected with cytopathic and non-cytopathic viruses. J. exp. Med. 121, 477.

Ogawa, K., Mizunu, N. \& OKamoto, M. (I96I). Lysosomes in cultural cells. J. Histochem. Cytochem. 9, 202.

PITT, D. (1968). Histochemical demonstration of certain hydrolytic enzymes within cytoplasmic particles of Botrytis cinerea Fr. J. gen. Microbiol. 52, 67.

Pitt, D. \& WaLkeR, P. J. (1967). Particulate localization of acid phosphatase in fungi. Nature, Lond. 215, 783 .

RobBins, E., Marcus, P. I. \& Gonatus, N. K. (1964). Dynamics of acridine orange-cell interaction. II. Dye-induced ultrastructural changes in multi-vesicular bodies (acridine orange particles). J. Cell Biol. 21, 49.

Rutenberg, A. M. \& Selrgman, A. M. (I955). The histochemical demonstration of acid phosphatase by a post-incubation coupling technique. J. Histochem. Cytochem. 3, 455 .

Rutenberg, A. M., Cohen, R. B. \& Seligman, A. M. (1952). Histochemical demonstration of aryl sulphatase. Science, N.Y. I16, 539.

Rutenberg, A. M., Rutenberg, S. H., Monis, B., Teague, R. \& Seligman, A. M. (1958). Histochemical demonstration of $\beta$-D-galactosidase in the rat. J. Histochem. Cytochem. 6, I 22.

Seligman, A. M., Tsou, K. C., Rutenberg, S. H. \& Cohen, R. B. (I954). Histochemical demonstration of $\beta$-D-glucuronidase with a synthetic substrate. J. Histochem. Cytochem. 2, 209.

SEMADENI, E. G. (1967). Enzymatische Charakterisierung der Lysosomenäquivalente (Sphärosomen) von Maiskeimlingen. Planta 72, 91 .

VORBRODT, A. (1961). Histochemical studies on the intracellular localization of acid deoxyribonuclease. J. Histochem. Cytochem. 9, 647.

Wachstein, M., Meisel, E. \& Falcon. C. (196I). Histochemistry of thiolacetic acid esterase: a comparison with non-specific esterase with special regard to the effect of fixatives and inhibitors on intracellular localization. J. Histochem. Cytochem. 9, 325.

\section{EXPLANATION OF PLATES}

\section{Plate I}

Fig. I. Uninfected potato tuber tissue section, fixed, stained for acid phosphatase by the coupling azo dye method. Note many small particles. $\times 733$.

Fig. 2. Section of potato tuber tissue 4 days after infection with Phytophthora erythroseptica, treated as above. Fewer particles are visible, remaining particles may be greatly enlarged. Note diffuse stain. $\times 733$.

Plate 2

Fig. 3. Section of healthy potato tuber tissue stained for acid phosphatase by the standard coupling azo dye method after fixation. Note many small particles, particularly in the vascular tissues. $\times 358$. 
Fig. 4. Section of infected potato tuber tissue 7 days after inoculation, stained for acid phosphatase as in fig. 3 . Note intense diffuse staining in vascular tissues. $\times 358$.

Plate 3

Fig. 5. Callus cells stained for acid phosphatase by the coupling azo dye method, post-fixed in cold neutral formalin. Note many discrete particles. $\times 500$.

Fig. 6. Callus cell $48 \mathrm{hr}$ after infection with discs of Phytophthora erythroseptica, fixed and stained as in fig. 5. Note enlarged particles some of which have coalesced, also intense diffuse staining. $\times 500$.

\section{Plate 4}

Fig. 7. Tissue culture cell from suspension culture to which euchrysin $3 \mathrm{R}$ had been added. Photographed by using incident fluorescence and low intensity dark-ground transmitted light microscopy $\mathrm{I} \mathrm{hr}$ after addition of dye, and $3 \mathrm{hr}$ after inoculation of the original culture with a mycelial suspension of Phytophthora erythroseptica. Note intense pinpoints of bright fluorescence (green and orange in original). $\times 266$.

Fig. 8. Same cell as fig. 7 incubated in a damp chamber and photographed $24 \mathrm{hr}$ after inoculation. Note many of original particles are no longer visible. $\times 266$.

Fig. 9. Healthy tissue culture cell from suspension culture to which euchrysin $3 R$ had been added. Photographed by fluorescence microscopy. Note many small brightly-fluorescing particles (green and orange in original). $\times 266$. 
Journal of General Microbiology, Vol. 53, No. 2

Plate I

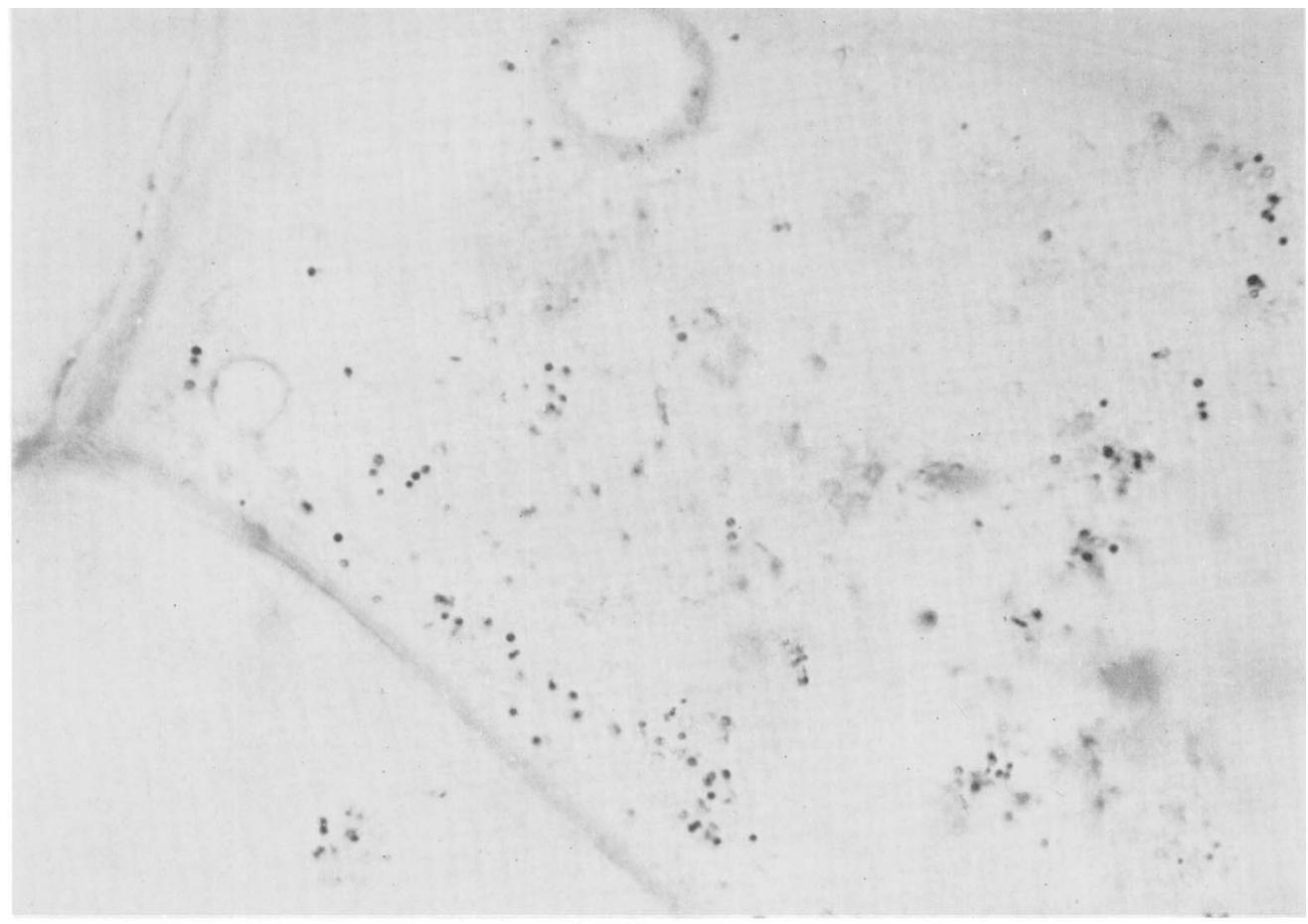

Fig. I

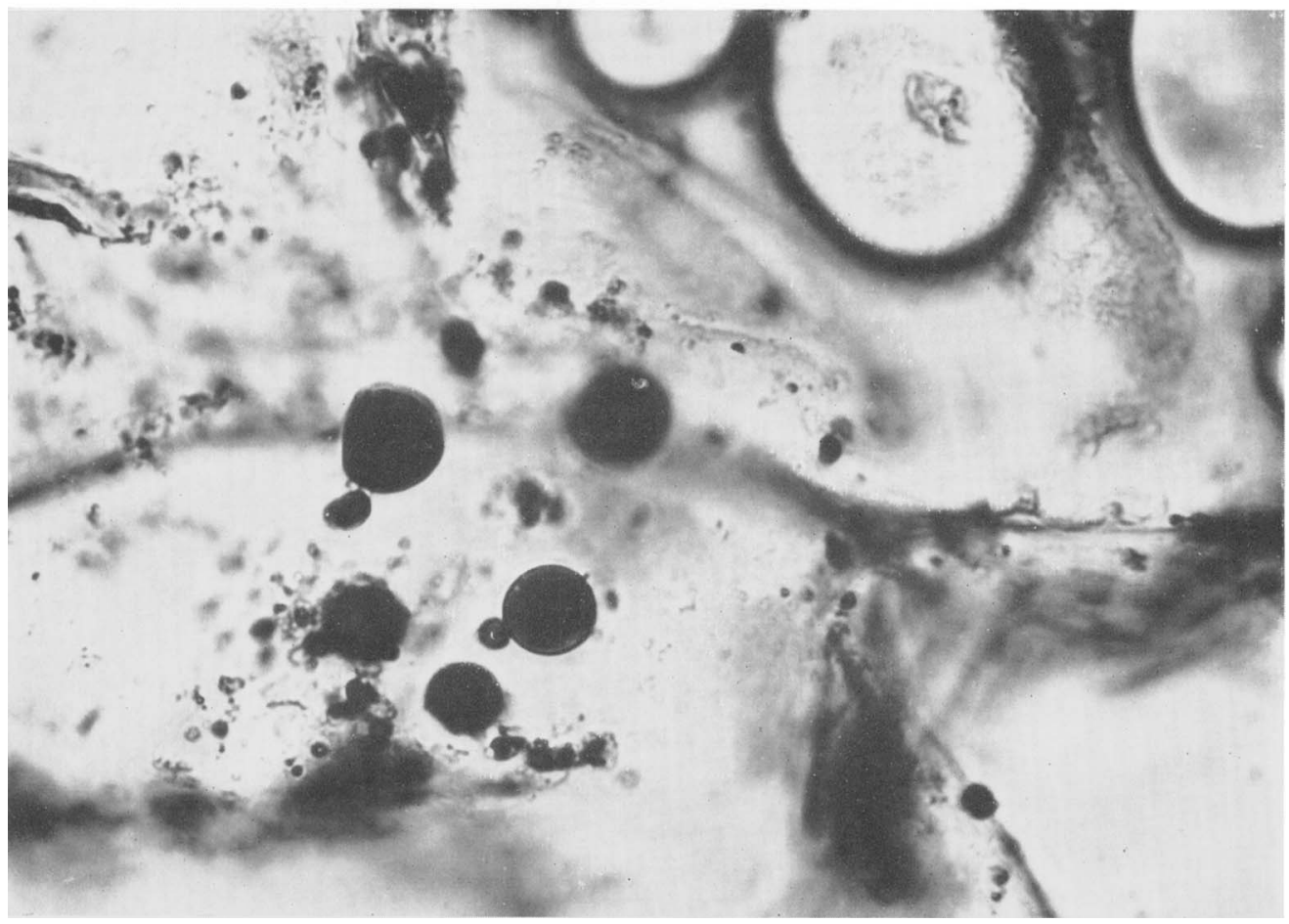

Fig. 2

D. PITT AND C. COOMBES

(Facing p. 204) 
Journal of General Microbiology, Vol. 53, No. 2

Plate 2

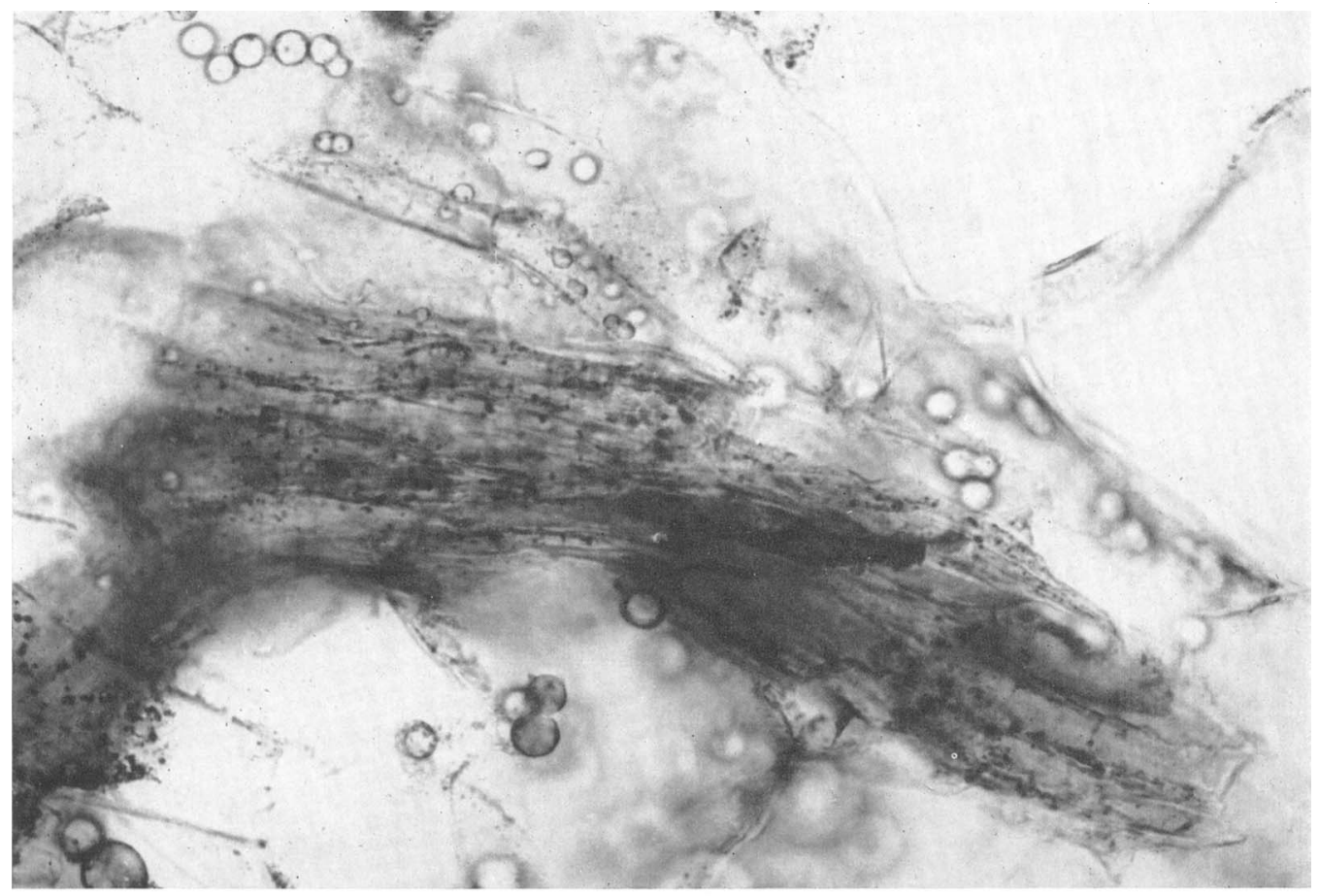

Fig. 3

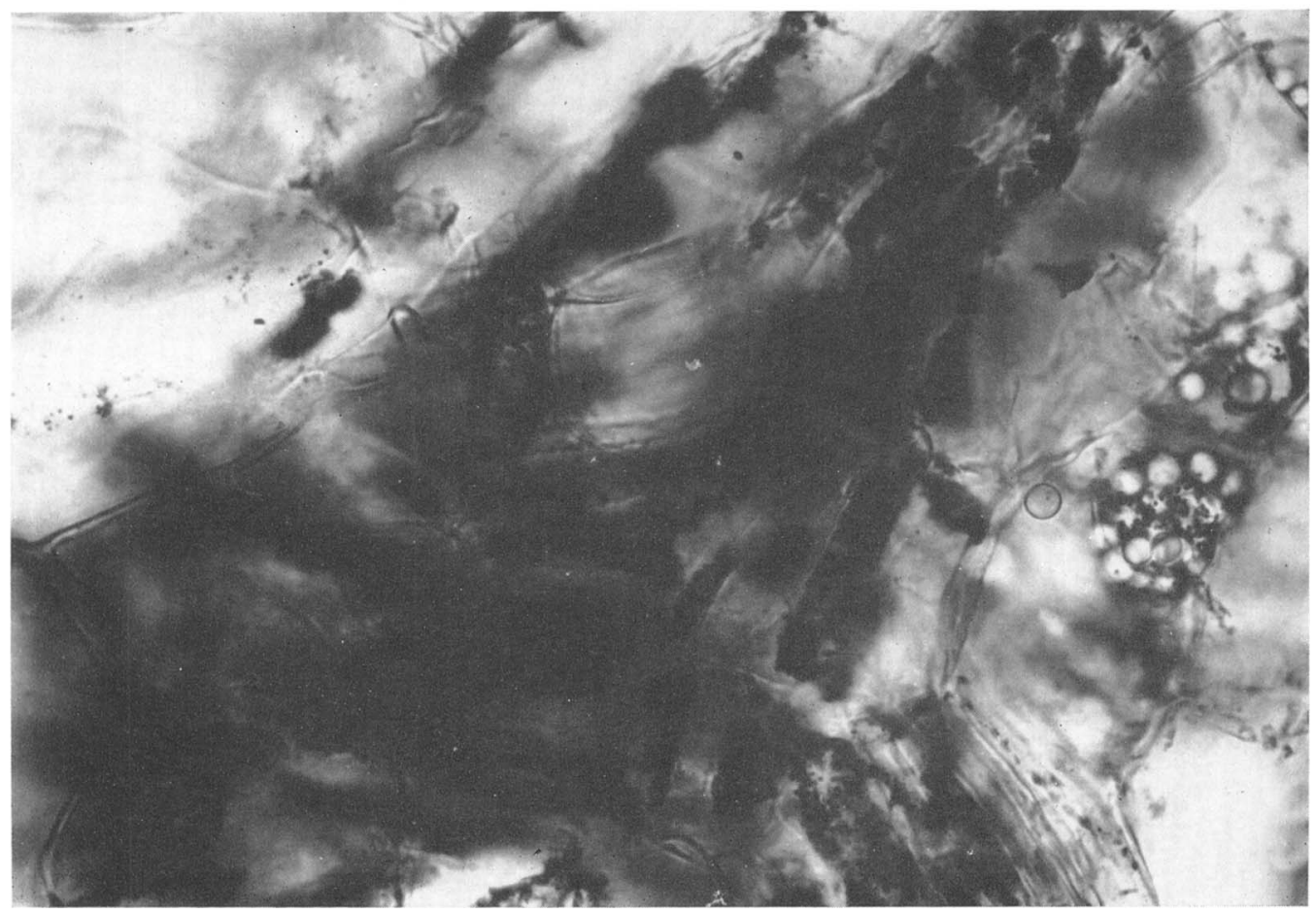

Fig. 4

D. PITT AND C. COOMBES 


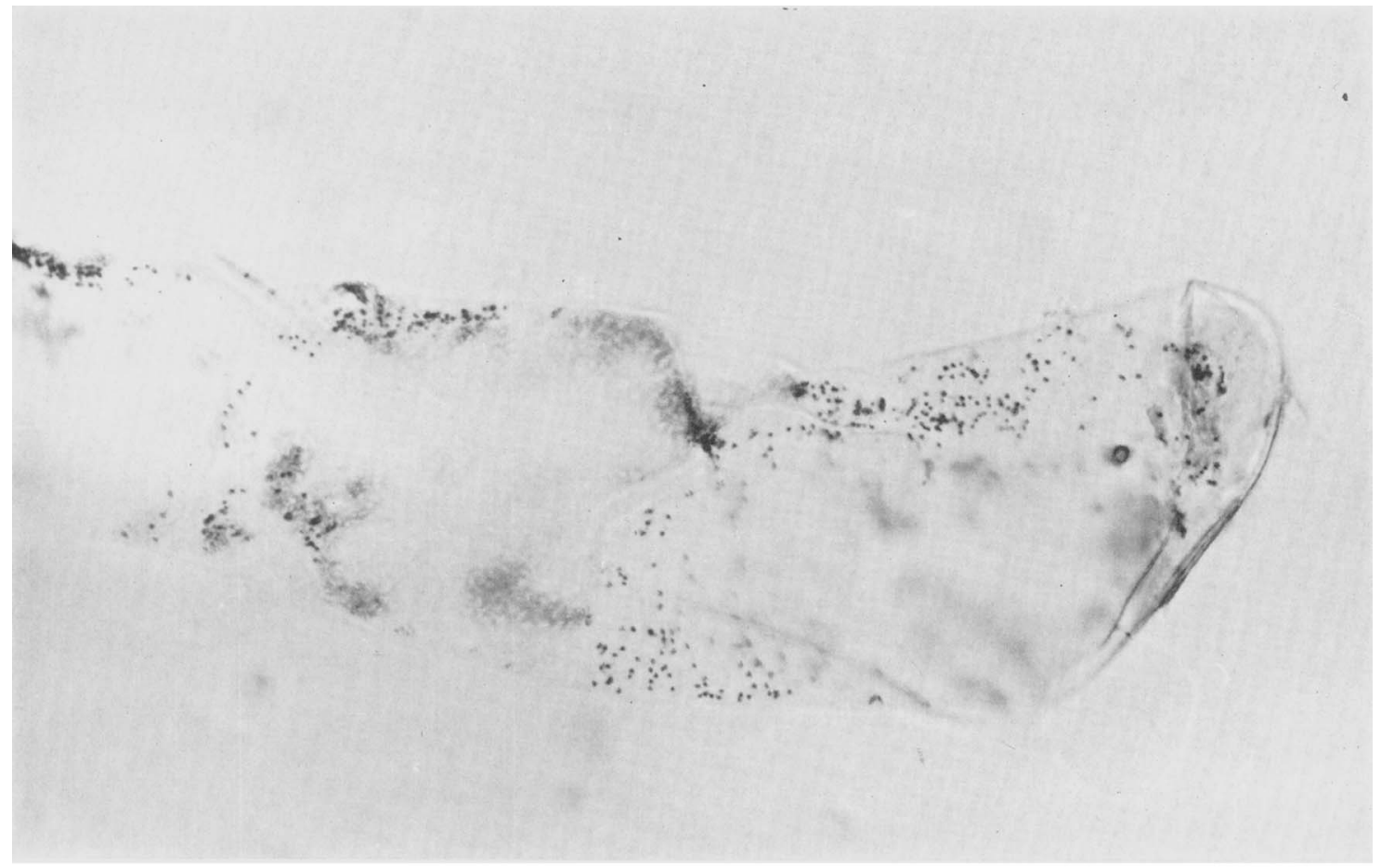

Fig. 5

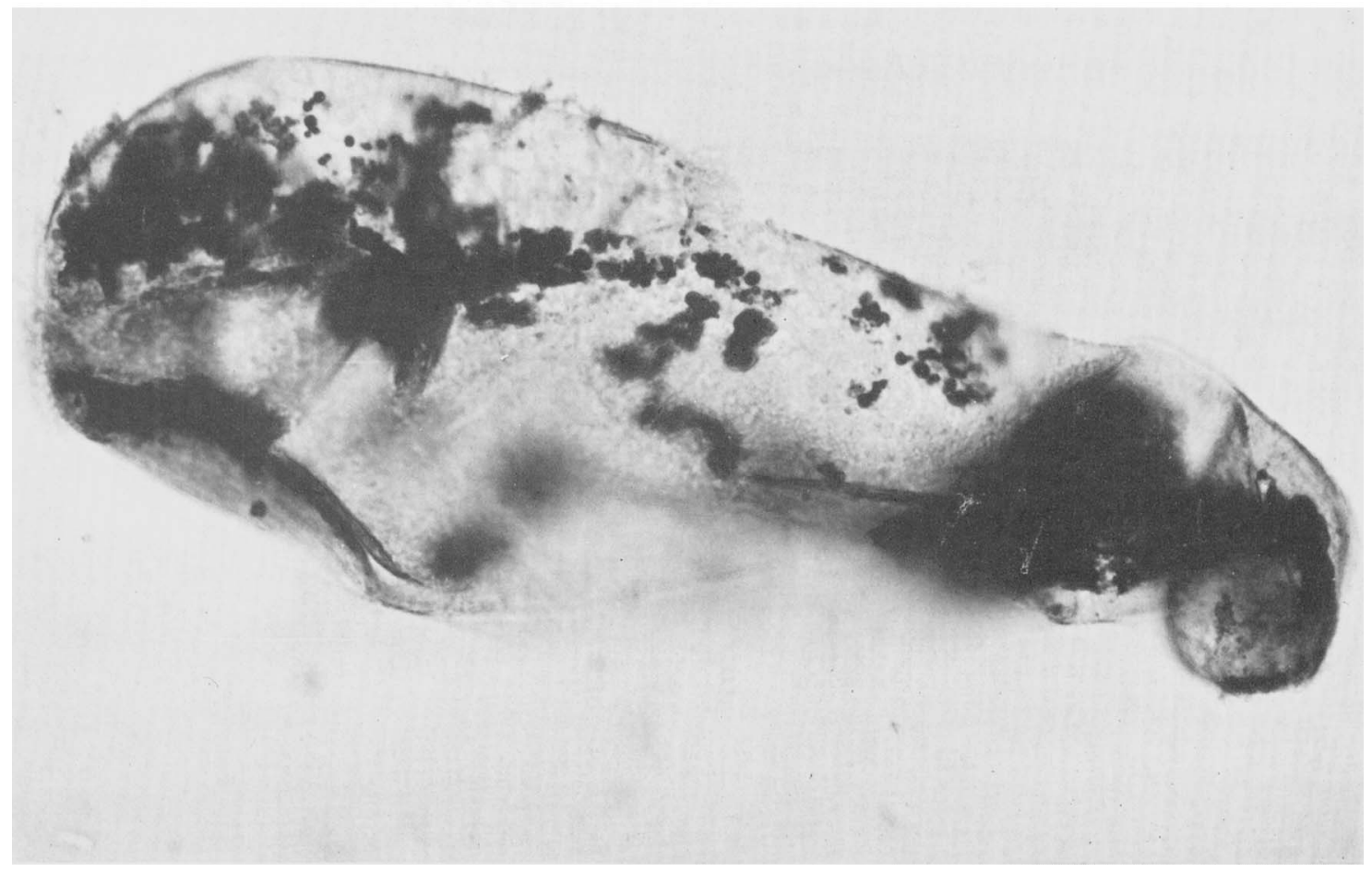

D. PITT AND C. COOMBES

Fig. 6 
Journal of Gencral Microbiology, Vol. 53, No. 2

Plate 4

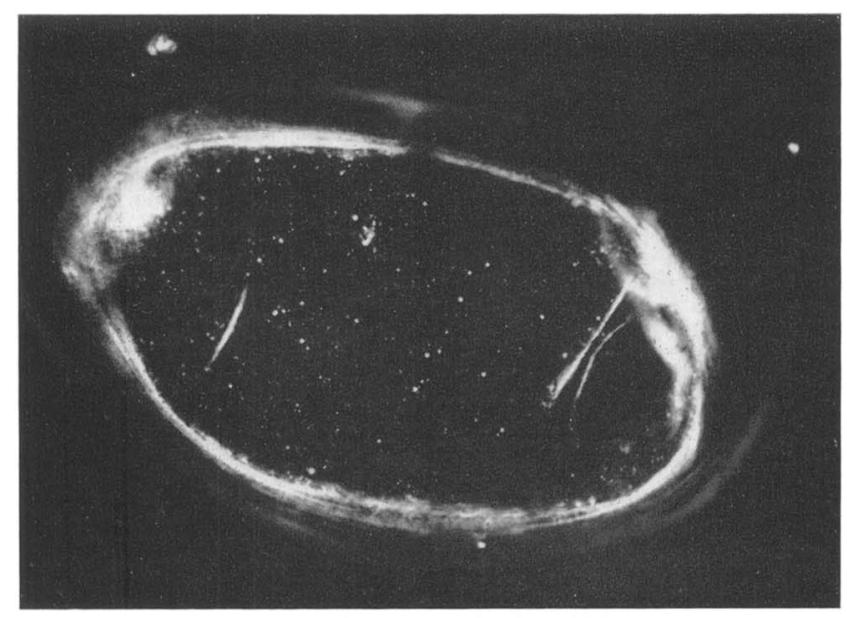

Fig. 7

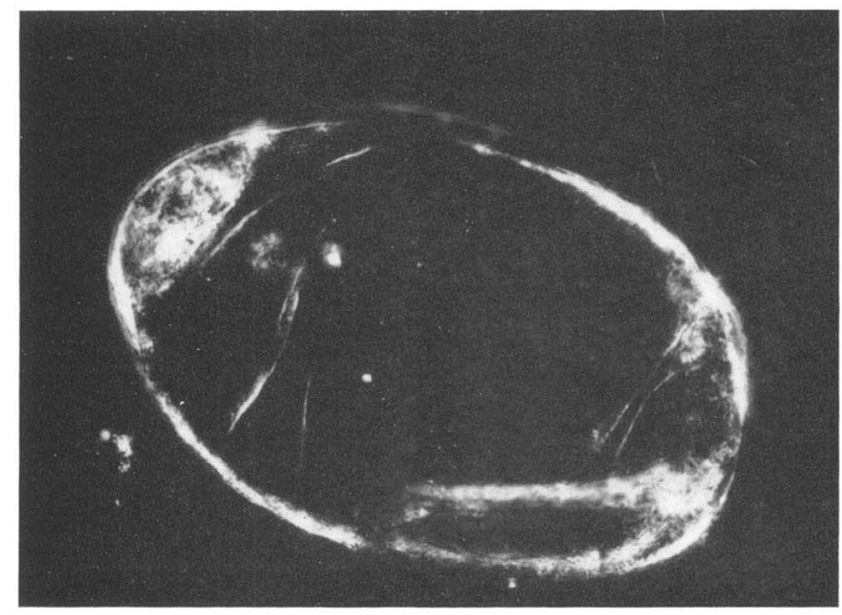

Fig. 8

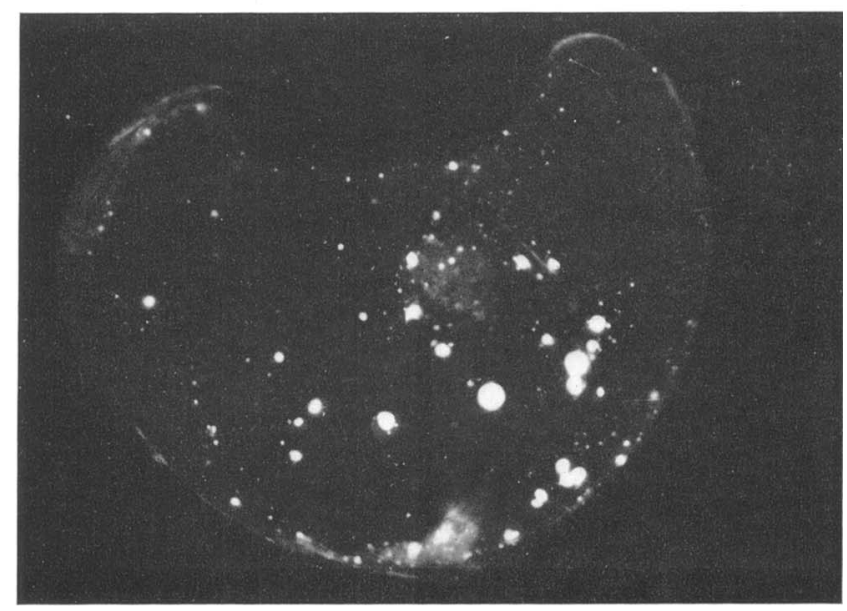

Fig. 9

D. PITT AND C. COOMBES 